\title{
事務所建物の火災安全性能評価方法の提案
}

一事前チェックリスト診断結果から焼損被害を推定一

\section{A STUDY ON METHOD OF EVALUATING FIRE SAFETY IN OFFICE FACILITIES}

- Method for the estimating the fire damage area by the beforehand questionnaire survey -

\section{佐 藤博臣*, 村井裕 樹**, 栗岡 均***, 志田弘二**** \\ Hiroomi SATOH, Hiroki MURAI, Hitoshi KURIOKA and Kouji SHIDA}

\begin{abstract}
Authors discussed on a method to estimate the fire damage area in existing office buildings by the beforehand questionnaire sheet survey.

A questionnaire sheet was developed taking into consideration the score pointed not only the substantiality degree of the hardware factors, but also the substantiality degree of the software factors.

A survey was conducted on experimentally 185 existing office buildings with the above-mentioned questionnaire sheet.

As a conclusion, authors made clear what might calculate the fire safety index to be able to perform comparison of the fire safety performance between the building easily with the above-mentioned questionnaire sheet, and what might estimate the fire damage area before firebreak.
\end{abstract}

Keywords : Evaluation method of fire safety, Statistics data, Fire damage area, Questionnaire, Office facility 火災安全評価、統計データ、焼損床面積、アンケート、事務所建物

\section{1 はじめに}

建築基準法の改正に伴う性能設計への流れから、建物の火災安全 性能をよりどころとした設計方法への道が開きつつある。しかし、 建物自体の火災安全性を高め、火源や可燃物などの日常の管理を徹 底し、火災安全性の高い建物を実現してもその努力が報われる制度 が社会的に少ない。これは、建物の管理状況や防火設備の設置状沉 など、日常管理を含めた調査を行い、その充実状況が火災安全性に 影響を与えるかどうかの分析、およびその結果をふまえた建物の火 災安全性を評価するツールが少ないことも原因の一つと考えた。

然るに、建物の火災リスクの定量的評価に関しては、関沢らの火 災統計分析 ${ }^{12}{ }^{2)}$ 、「火災報告」注2) を基にした野崎・小林らの研究3) 4) 5)、正規化リスク曲線を用いた水野の一連の研究6) 7) 8) 、著者等 の焼損床面積の累積相対度数分布の研究9) などがある。これらの分 析のベースとしての「火災報告」は、消防用設備の設置など法に定 める安全対策と火災損害の関係を把握するには非常に有用である。 しかし、「火災報告」には、具体的な火災の拡大を支配する空間内部 の可燃物配置など空間の使い方に関する情報や建物の日常管理状況 など火災安全性能に大きく影響する可能性のある情報が不足してい る。

一方、既存建物の消防用設備などの設置状況に加えて「火災報告」
では入手が困難な設備点検の実態やその他の火災安全対策（特に日 常管理など建物を使う人の行動や意識による貢献）の状況について は、火災工学的な知見をよりどころとする複数の項目からなるチェ ックリストに基づくアンケート調査などを行うことで事前の火災安 全上の特徴として建物毎にデータ化することが可能である。しかし、 この種の方法では、評価対象物の相対的な弱点を指摘することがで きるが、対策の総合評価を定量化するのは容易ではなく、火災が発 生した場合の損害を推定することはできない。

そこで本研究では、アンケート調查分析と「火災報告」の統計分 析を比較検討し、両者の結果を関連付けた火災安全性能評価手法の 構築を行う。具体的には、対象とする建物の日常管理状況や防火設 備の設置などの充実状況に関する事前アンケート調査に基づく火災 安全性評価結果から被害状況（焼損床面積・焼損率等の物的被害） を推定する方法を確立することを最終的な目的とした。

\section{2 研究の構成}

本研究で目標とする火災安全性能評価のプロトタイプ構築のため には、比較的母集団が大きく、利用の形態や安全対策が均質と想定 される事務所建物を分析対象として適切と判断した。

ここで「事務所建物」とは、一般に建築に関わる人々が想定（机
* イー・アール・エス 博士 (工学)

** 兵庫県立福祉のまちづくり工学研究所 博士 (工学)

*** 鹿島技術研究所 博士 (工学)

**** 名古屋市立大学大学院芸術工学研究科 教授. 工博
Engineering \& Risk Services Corp., Dr. Eng.

Hyogo Assistive Technology Research and Design, Dr. Eng.

Kajima Technical Research Institute, Kajima Corp., Dr. Eng.

Prof., Nagoya City Univ., Dr. Eng. 


\begin{tabular}{|c|c|c|c|c|}
\hline \multirow{2}{*}{ 建築物の全体的概要 } & \multicolumn{2}{|c|}{ ソフト要因 } & \multicolumn{2}{|c|}{ ハード要因 } \\
\hline & 防火管理体制 & 設備等の点検体制 & 代表室の安全対策 & その他部分の安全対策 \\
\hline ビルの使用形態 (所有・テナント) & 管理組織の有無 & 点検頻度 & 感知設備の有無 & 避難経路のわかりやすさ \\
\hline 従業員数 & 巡回の有無 & 点検後の改善方法 & 消火設備の有無 & 防火戸等の閉鎖障害 \\
\hline 竣工年 & 防火管理者等の選任 & 重要設備の点検状況 & 可燃物の状況 & 可燃物の状況 \\
\hline 床面積·階数 & 消火等訓練の実施 & 改善の意思伝達 & 扉の状況 & 排煙設備の有無 \\
\hline 構造 & 従業員の意識 & & 排煙設備の有無 & \\
\hline 管理形態 (総合·設備) & 消防計画書の有無 & & & \\
\hline 代表室の面積・内装等 & 自衛消防隊の有無 & & & \\
\hline
\end{tabular}

の上で事務・執務などを行う空間及びそれに付属する空間 (会議室・ 応接室・トイレ・小規模な倉庫など）を含む）している執務空間で 構成される建物である。しかし、上記「火災報告」には、このよう な執務空間などと一致する統計デー夕は存在しない。そこで便宜的 に類似用途が多数含まれる消防法施行令の別表第一の(15)項（その 他の事業場）から「事務所」の建物火災として分類されたものを用 いた。

本研究に先立ち、建物の防火上の安全対策および消火設備・報知 設備等の設置状況（以降、ハード要因と定義）の充実度合と日常管 理など建物の維持管理状況および消火・報知設備等の点検状況（以 降、ソフト要因と定義）による対応力などを、過去の研究や火災事 例分析などの知見を基に考慮した、マクロ的な建物の火災安全性を 評価するアンケートシートを試作した。

本研究は、この試作シートによる結果と火災報告データを用いて 以下を提案した。

(1) 試作したアンケートシートを用いて既存事務所建物の調査を行 い、データを収集するとともに併せてそのシートの適用性を検討 した。すなわち、建物の延焼拡大に関連する項目の重要性などを 加味して得点化を行い、その得点を当該建物の火災安全性とし、 さらにこれを簡便化した指標として火災安全指数を提案した。

(2) アンケートシートと「火㷋報告」で共通項目に着目して、「火災 報告」の焼損床面積、焼損率注 ${ }^{3)}$ について分析した。さらに前記 した火災安全指数が持つと想定される被害規模の概略イメージと して、火災時に予想される焼損床面積や焼損率を推定寸る方法を 提案した。

\section{3 アンケート調査分析}

\section{1 アンケート調査の位置付け}

建物の火災安全に関わる管理は、本来ならば建物所有者や建物利 用者（テナント従業員など）が中心となって行うべきである。しか し現実には、事務所建物においては建物管理会社一委託して行われ ることが多い。このような建物管理の実情から、建物管理担当者な どが比較的容易に調査できる項目で、建物の火災安全性を説明でき る客観的な指標を作成することが重要と考えた。

試作したアンケートの調查項目と内容は、建物管理担当者の調 查・記入を想定し、建築計画や火災安全性などに関しても専門的知 識を必要とする内容は極力控え、建物の用途が同じならば、どの建 物でも共通して必要となると考えられる火災安全性に関する基本的 な項目を主とした。

\section{2 調査項目と配点}

建物は、法規で要求される項目に概称従って建設されていると考 え、調查項目には法令設置義務の確認とした内容も一部あるが、法

\section{表 2 アンケート選択肢と配点例}

\begin{tabular}{|c|c|}
\hline \multicolumn{2}{|l|}{ Q.火災安全に関する会議の実施等 } \\
\hline 選択肢 & 配点 \\
\hline 1. 会議は行われていない(記録もない) & 0 \\
\hline 2. 会議は行われているが、記録はない & 1 \\
\hline 3. 会議が行われてその内容が記録・保管されている & 1 \\
\hline が、従業員へはその内容を伝えていない & \\
\hline $\begin{array}{l}\text { 4. 会議が行われてその内容が記録・保管され、従業 } \\
\text { 抜粋も含む)を伝えている }\end{array}$ & 2 \\
\hline 5. その他 & 1 \\
\hline \multicolumn{2}{|l|}{ Q.消防防災設備・機器の点検の実施等 } \\
\hline 選択肢 & 配点 \\
\hline 1. 点検を実施していない & 0 \\
\hline 2. 法規 (法定)未満の頻度で点検を実施している & 0 \\
\hline 3. 法規 (法定) 通りの頻度で点検を実施している & 1 \\
\hline 4. 法規 (法定) 通り以上の頻度で点検を実施している & 2 \\
\hline 5. 設備機器によって異なるので一概に回答できない & 1 \\
\hline 6. 分からない & 0 \\
\hline 7. その他 & 0 \\
\hline \multicolumn{2}{|l|}{ Q.代表的な事務室への排煙設備設置 } \\
\hline 選択肢 & 配点 \\
\hline 1. 設けられている & 1 \\
\hline 2. 設けられていない & 0 \\
\hline \multicolumn{2}{|l|}{ Q.郎下・エレベータホールなどの書類やゴミなど } \\
\hline 選択肢 & 配点 \\
\hline 1. 常に放置されている & 0 \\
\hline 2. 時々あるいは場所によって置かれている & 0 \\
\hline 3.いいえ & 1 \\
\hline
\end{tabular}

\section{表 3 アンケート実施状況}

\begin{tabular}{|c|c|c|c|c|c|}
\hline 実施時期 & 対象 & 発送数 & $\begin{array}{c}\text { 有効 } \\
\text { 回収数 }\end{array}$ & $\begin{array}{c}\text { 有効 } \\
\text { 回收率 }\end{array}$ & $\begin{array}{c}\text { 平均 } \\
\text { 延床面積 }\end{array}$ \\
\hline 2002年3月 & 全国 & 844 & 185 & $21.9 \%$ & $10451.5 \mathrm{~m}^{2}$ \\
\hline
\end{tabular}

\section{表 4 分析に用いた建物の面積区分}

\begin{tabular}{|l|l|l|}
\hline & 面積区分 $\left(\mathrm{m}^{2}\right)$ & \multicolumn{1}{|c|}{ 要件 } \\
\hline 事 & $0 \sim 150$ & \\
務 & $150 \sim 300$ & $150 \mathrm{~m}^{2}$ 以上で防火管理者選任 \\
\cline { 2 - 3 } 所 & $300 \sim 1000$ & $300 \mathrm{~m}^{2}$ 以上で消火器具設置 \\
\cline { 2 - 3 } & $1000 \sim$ & $1000 \mathrm{~m}^{2}$ 以上で自動火災報知設備設置 \\
\hline
\end{tabular}

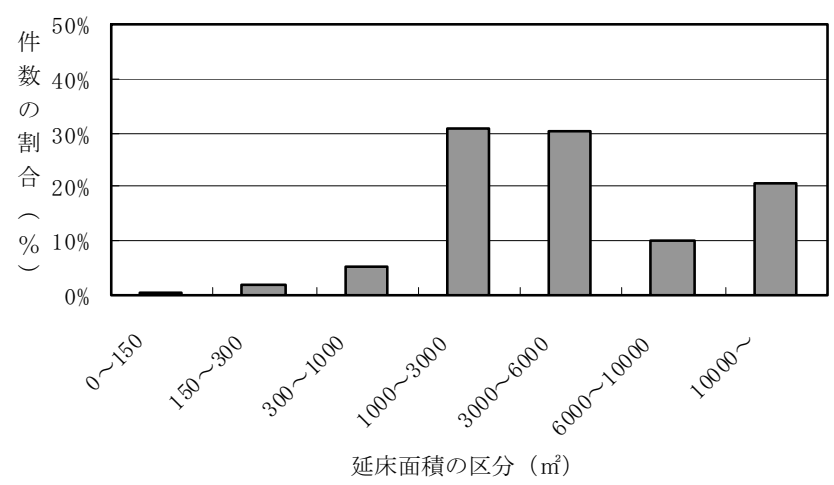

図 1 アンケート回答の延床面積の分布（有効回収 185 件） 


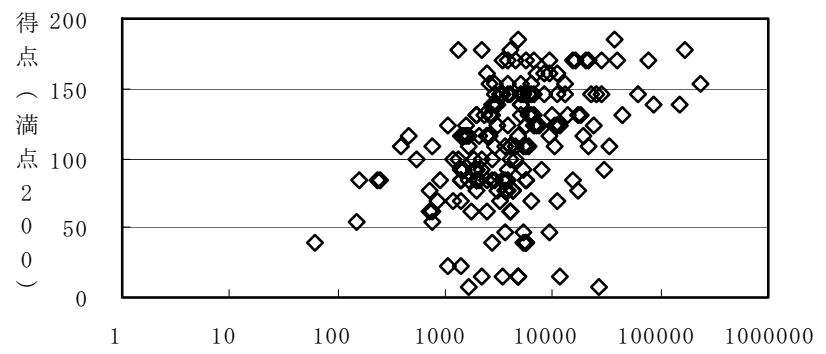

延床面積 $\left(\mathrm{m}^{2}\right)$

図 2 延床面積とソフト要因の得点分布 $\quad(n=185)$

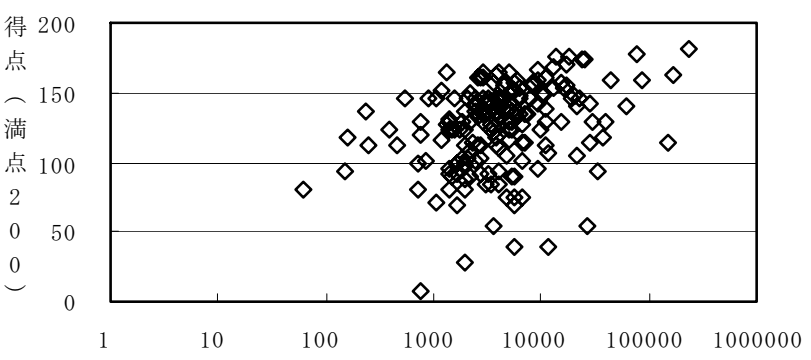

延床面積 $\left(\mathrm{m}^{2}\right)$

図 3 延床面積とハード要因の得点分布 $\quad(n=185)$

規以上の性能の把握に努めた。具体的には、建物の概要（面積、階 数など）の他に、表 1 に示すソフト要因 2 分類（「防火管理体制」、

「設備等の点検体制」)、ハード要因 2 分類 (「代表室・最重要室の防 火関係設備など火災安全対策」(以下「代表室の対策」)、「その他室・ 共用部等の防火関係設備など火災安全対策」（以下「その他室の対 策」)）である。全設問数は約 60 項目13)である。

建物の火災安全性に対するソフト要因とハード要因の充実状況に 着目し、アンケート結果を得点化して建物の火災安全性を評価した。 具体的には、アンケートの選択肢を「良い状況」と「悪い状況」に 分け、それぞれ配点を 1 点と 0 点とし、特に経験的に火災安全性の 向上に重要と考えられる選択肢は 2 点とした（なお、無回答の場合 は 0 点とした)。アンケートの設問、選択肢、配点例を表 2 に示す。 各設問を、表 1 に示寸「防火管理体制」「設備等の点検体制」「代表 室の対策」「その他室の対策」の 4 つのいずれかに分類し、それぞれ の分類ごとに合計した得点をさらに各 100 点満点に基準化(合計 400 点となる）し相互比較が可能となるようにした。

\section{3 アンケートの結果・考察}

アンケートは、鹿島建物総合管理株式会社が管理する全国の事務 所建物に対して実施した。発送数、回収数などを表 3 に示す。回答 建物の代表特性として、消防用設備など防火対策と関係の深い延床 面積を横軸に、建物数を縦軸として図 1 に示した。分析に用いた建 物の面積区分は「火災報告」に記載された事務所建物を対象に、建 物を消防法令による消防用設備等の設置要件となる延床面積を境界 として表 4 のように分類して分析した。表 3 の右欄の平均延床面積 は有効回答全体の平均を示したものである。図 1 に示したように回 答建物の多く(約 8 割) は $1000 \mathrm{~m}^{2}$ 以上 $10000 \mathrm{~m}^{2}$ 未満であった。図 2 と図 3 は、縦軸にアンケートの得点 (ソフト要因、ハード要因)、横 軸に延床面積（対数軸）をとったものである。全体的にはソフト要 因よりもハード要因の方が得点のばらつきが小さい。10000 $\mathrm{m}^{2} を$ 超 える大規模な建物では、ソフト・ハードの得点共に相対的に大きな

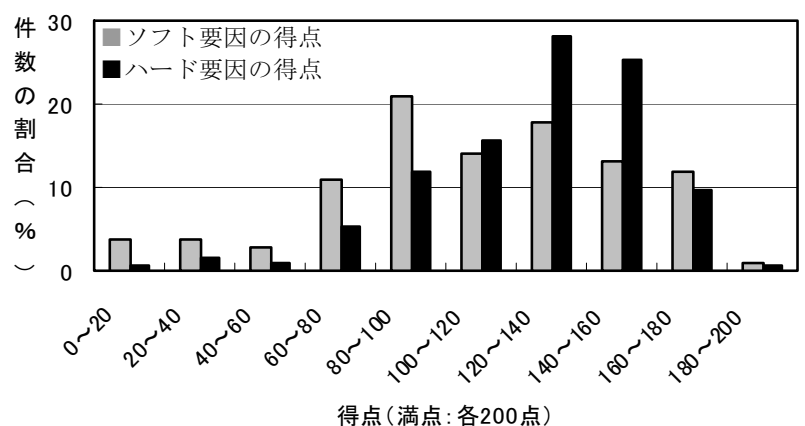

図 4 ソフト・ハード要因の得点分布 $\quad(n=185)$

表 5 ソフト・ハード要因ごとの得点 $\quad(n=185)$

\begin{tabular}{|c|c|c|c|c|c|}
\hline & \multicolumn{2}{|c|}{ ソフト要因 } & \multicolumn{2}{|c|}{ ハード要因 } & \multirow{2}{*}{$\begin{array}{l}\text { ソフト・ } \\
\text { ハーード } \\
\text { 合計点 }\end{array}$} \\
\hline & $\begin{array}{c}\text { 防火 } \\
\text { 管理体制 }\end{array}$ & $\begin{array}{l}\text { 点検 } \\
\text { 体制 }\end{array}$ & $\begin{array}{l}\text { 代表室 } \\
\text { の対策 }\end{array}$ & $\begin{array}{c}\text { その他室 } \\
\text { の対策 }\end{array}$ & \\
\hline (満点) & 100.0 & 100.0 & 100.0 & 100.0 & 400.0 \\
\hline 平均点 & 47.8 & 61.9 & 57.7 & 67.8 & \multirow{3}{*}{235.2} \\
\hline 標準偏差 & 28.1 & 19.6 & 17.9 & 17.8 & \\
\hline 平均点合計 & \multicolumn{2}{|c|}{109.7} & \multicolumn{2}{|c|}{125.4} & \\
\hline
\end{tabular}

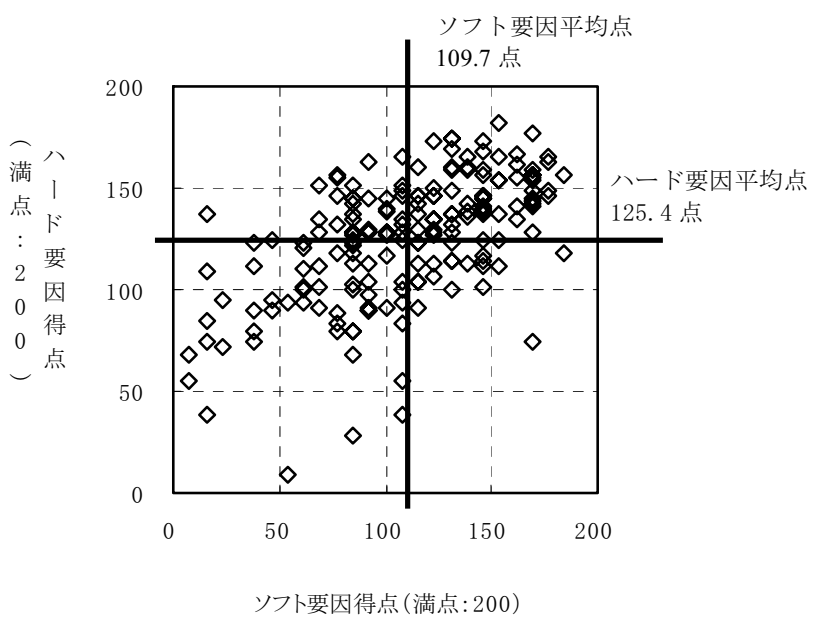

図 5 ソフト・ハード要因の得点の対応状況 $\quad(n=185)$

值を示し、ばらつきも少ない。また $1000 \mathrm{~m}^{2}$ を回る小規模な建物 では、ソフト・ハードの得点共に相対的に小さな值を示し、ばらつ きも少ない。この間の規模の建物では、ソフト・ハード共に得点の ばらつきが大きい。

アンケートの得点概要を表 5 に示す。ソフト要因のほうがハード 要因よりも平均点が低く、ばらつきも大きかった。図 4 にハード及 びソフト要因のそれぞれの得点分布（各 200 点満点）を示す。

図 4 のソフト要因に関しては、0 点〜 60 点の範囲の極端に低い得 点の建物は少なく、平均点よりも高得点側の日常管理状況の良い状 況に建物が偏る傾向があった。

ハード要因もソフト要因と同様に、平均点付近に多くの建物が分 布した傾向を示した。120 点〜180 点の範囲に約 50\%の建物が集中 し、比較的高得点の場合が多い。一方で非常に低い得点の建物もあ る。これらの存在は、ハード要因に関しては消火設備や報知設備な ど法令で設置義務のある項目の設問以外に、法規以上の安全対策の 実施状況の把握に努めたことに起因すると判断する。

図 5 に回答のあった 185 件のデータのソフト要因とハード要因の 相互の関係を示す。ハード要因に比べてソフト要因のほうが幅広く 分布し、火災安全の視点における、建物利用者の日常管理との関わ り方（防災意識）に大きな差があることが推測できる。 
なお、ソフト要因とハード要因の得点の重み付けが重要となるが、 このような研究によってデータが蓄積されることで適正な重みが決 定されると考える。しかし、ここでは、図 4 に示したようにソフト 要因の得点分布とハード要因の得点分布の形状がやや異なってはい るが、おおむ類似の得点分布傾向であることから、以下の検討で は両者をほぼ同一の重みで評価した。

以上のことから、アンケートの項目や配点を適切に行い、データ の充実化を図れば、このような方法で建物の火災安全性能を事前に 評価できるものと判断した。

\section{4 「火災報告」分析}

\section{1 分析方法}

「火災報告」に記載される項目とアンケートの調査項目で共通寸
る項目と「火災報告」のみで分かる焼損床面積や焼損率を分析し、 火災安全性評価の方法の可能性を提案する。

「火災報告」分析の対象は、1996 年から 2002 年の 7 年間注 4) で、 爆発や放火などを除外した非木質系構造注 5) の火災 1012 件である。

「火災報告」とアンケート項目を対比すると、ソフト項目では防 火管理者の選任状沉、消防計画書の作成、消火訓練の実施の 3 項目、 ハード項目では消火設備の設置状沉および自動火災報知設備の設置 状沉の 2 項目、合計で 5 項目が共通であった。ソフト項目はハード 項目に合わせ 2 項目と寸ることが分析のしやすさから適切であるこ と、また消防法令の規定では防火管理者の選任が前提である消防計 画書の作成を外すこととした注6)。ここで、表 6 はアンケートと「火 災報告」の設問・選択肢の関係を示したものであるが、アンケート 分析と「火災報告」分析の点数で混乱を招かぬように、ポイントと

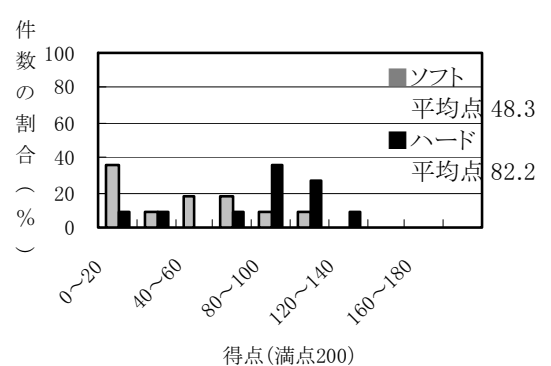

(a) $[\mathrm{S} 0, \mathrm{H} 1]$ 群の度数分布 $(\mathrm{n}=11)$

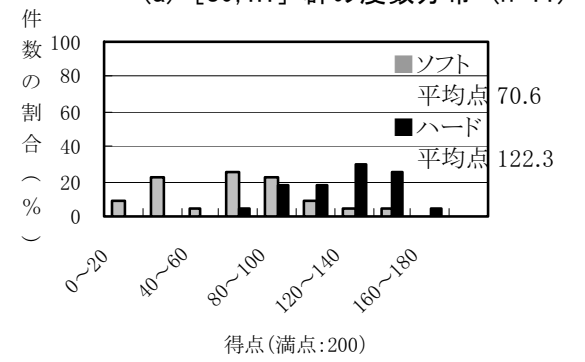

(d) $[\mathrm{S} 0, \mathrm{H} 2]$ 群の度数分布 $(\mathrm{n}=23)$

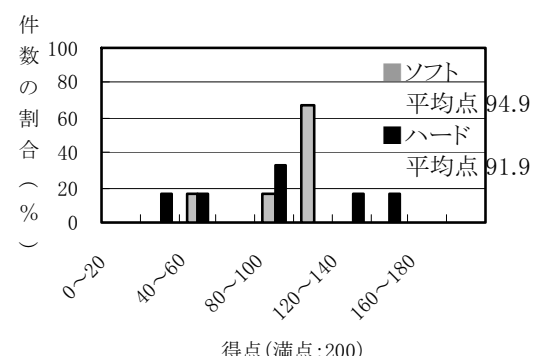

(b) $[\mathrm{S} 1, \mathrm{H} 1]$ 群の度数分布 $(\mathrm{n}=6)$

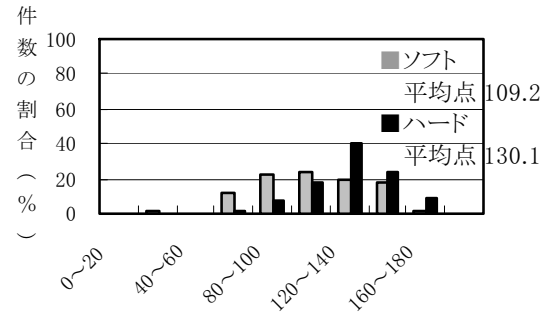

得点 (满点: 200)

(e) $[S 1, H 2]$ 群の度数分布 $(n=57)$

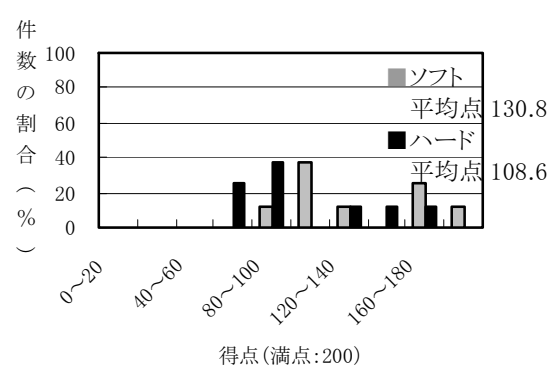

(c) $[\mathrm{S} 2, \mathrm{H} 1]$ 群の度数分布 $(\mathrm{n}=8)$

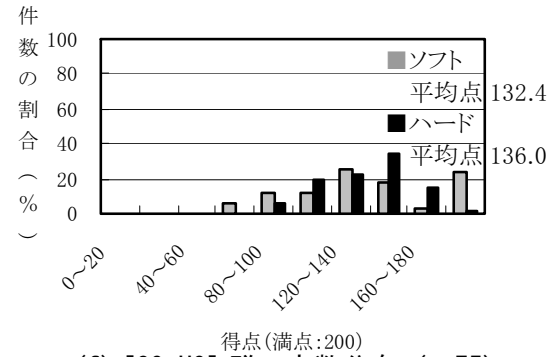

(f) $[S 2, H 2]$ 群の度数分布 $(n=75)$

図 6 ソフト・ハード要因の点数の組合せによる得点分布（事務所）

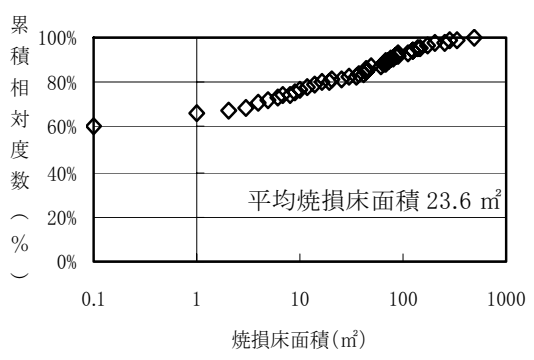

(a) $[\mathrm{S} 0, \mathrm{H} 1]$ 群の焼損床面積 ( $\mathrm{n}=165)$

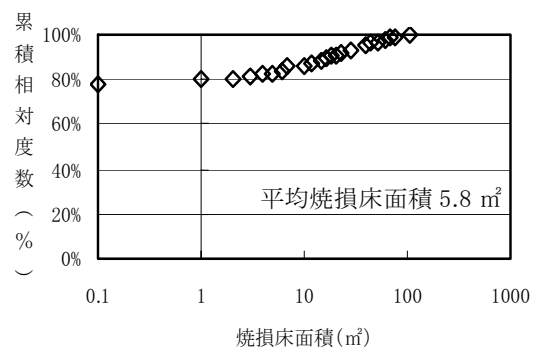

（d） [SO, H2] 群の焼損床面積（ $\mathrm{n}=124 ）$

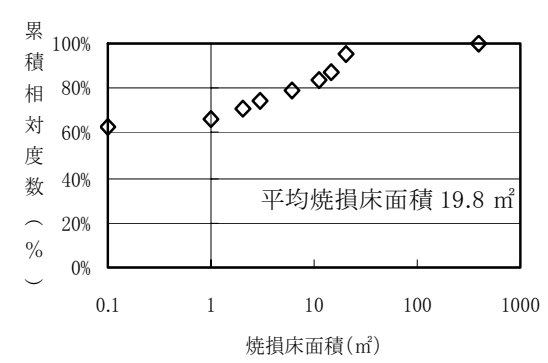

(b) $[S 1, \mathrm{H} 1]$ 群の焼損床面積 $(\mathrm{n}=24)$

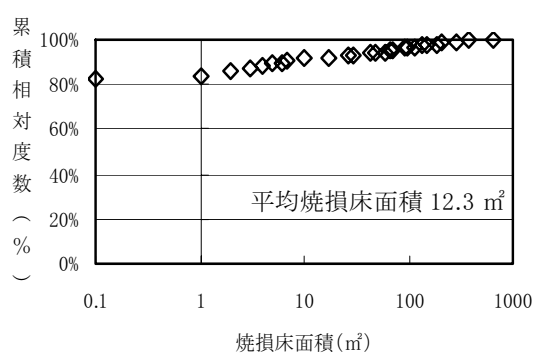

（e）[S1, H2] 群の焼損床面積（ $\mathrm{n}=222 ）$

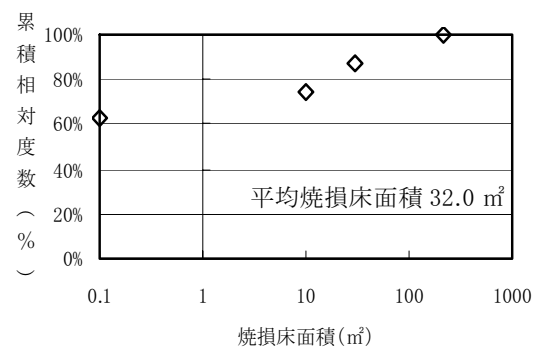

（c）[S2, H1] 群の焼損床面積 $(n=8)$

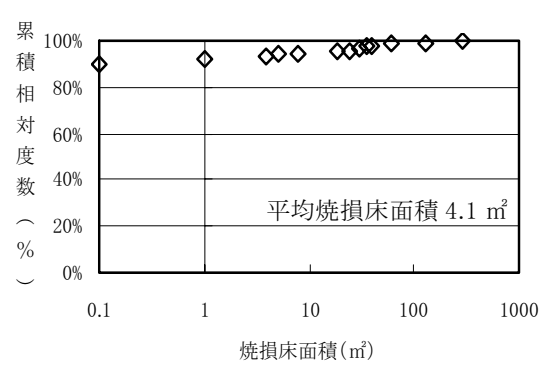

（f） [S2, H2] 群の焼損床面積（ $\mathrm{n}=167 ）$

図 7 ソフト・ハード要因のポイント組合せ区分による焼損床面積の累積相対度数 
呼ぶ得点を定義し、「良い状況」（例えば「防火管理者を選任してい る」「消火設備を設置している」など）の選択肢の場合はポイント 1 、 そうでない場合はポイント 0 と得点化した。

ソフト要因のポイントを $\mathrm{Sn}(\mathrm{n}=0,1,2)$ 、ハード要因のポイントを $\mathrm{Hn}(\mathrm{n}=0,1,2)$ として略し、例えばソフト 2 ポイント、ハード 1 ポイン トの建物は、 $[\mathrm{S} 2, \mathrm{H} 1]$ と表記した。このとき、同じ S1 と表記して も「防火管理者の選任状況」または「消火訓練の実施状況」のいず れか一方でポイント 1 であるとき、また同じく H1 と表記した場合 でも「報知設備の設置状況」または「消火設備の設置状況」のいず れか一方でポイント 1 である場合が考えられるが、防火管理者は選

\section{表 6 アンケートと「火災報告」の設問・選択肢の対応}

\begin{tabular}{|c|c|c|c|c|c|}
\hline \multicolumn{2}{|r|}{ 設問項目 } & \multicolumn{2}{|l|}{ アンケート調査 } & \multicolumn{2}{|c|}{ ポイント } \\
\hline \multirow{4}{*}{$\begin{array}{l}3 \\
7 \\
1\end{array}$} & 防火管理者の & 選任 & 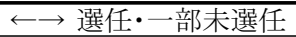 & 1 & \multirow{4}{*}{$\begin{array}{l}\text { 合計で } \\
0,1,2 \\
\text { (最大 } 2 \text { ) }\end{array}$} \\
\hline & 選任 & 未選任・不明 & $\leftarrow \rightarrow$ 非該当・未選任 & 0 & \\
\hline & 消火 & 実施 & $\rightleftarrows$ 実施 & 1 & \\
\hline & 実施 & 未実施・不明 & $\rightleftarrows \longrightarrow$ 非該当・実施せず & & \\
\hline \multirow{4}{*}{$\begin{array}{l}\text { 八 } \\
\text { l }\end{array}$} & 報知言 & 設置 & $\rightleftarrows$ 設置 & & \multirow{4}{*}{$\begin{array}{l}0,1,2 \\
\text { (最大 } 2 \text { ) }\end{array}$} \\
\hline & 設置 & \begin{tabular}{|c|} 
設置・不明 \\
\end{tabular} & Ł↔ 非該当・設置せず & 0 & \\
\hline & 消火 & 設置 & $\longleftrightarrow$ 設置 & 1 & \\
\hline & & 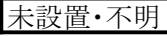 & $\rightleftarrows$ 非該当 & & \\
\hline
\end{tabular}

表 7 アンケート・「火災報告」共通項目で分類したアンケート得点

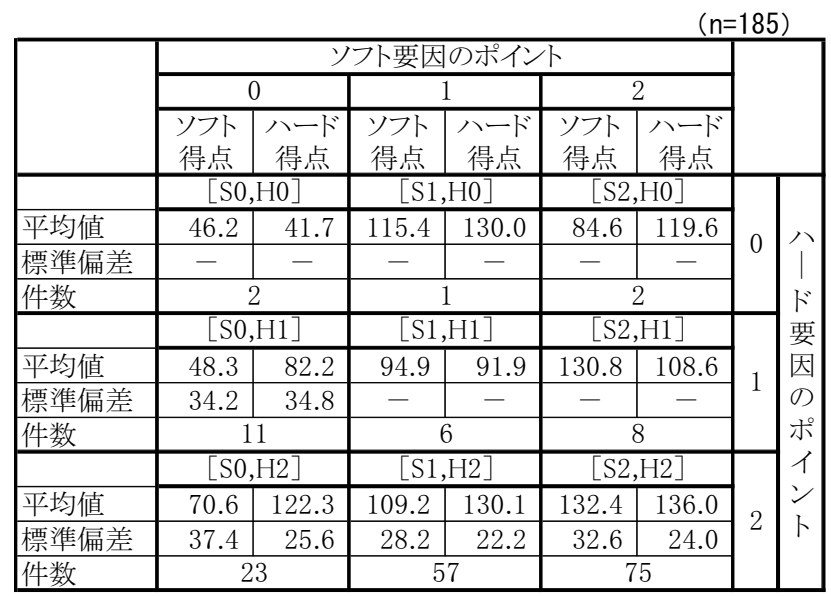

表 8 アンケート・「火災報告」共通項目で分類した 焼損床面積と焼損率の平均値 $(n=1012)$

\begin{tabular}{|c|c|c|c|c|c|c|}
\hline & \multicolumn{3}{|c|}{ ソフト要因のポイント } & & \\
\hline & & 0 & 1 & 2 & & \\
\hline & & {$[\mathrm{S} 0, \mathrm{H} 0]$} & $\overline{\mathrm{S} 1, \mathrm{H} 0}$ & $\mathrm{~S} 2, \mathrm{H} 0$ & & \\
\hline 焼損床面積 & 平均值 & 25.7 & 0.0 & 0.0 & & \\
\hline$\left(\mathrm{m}^{2}\right)$ & 標準偏差 & 64.6 & - & - & & \\
\hline 焼損率 & 平均值 & 28.3 & 0.0 & 0.0 & 0 & \\
\hline$(\%)$ & 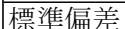 & 40.9 & - & - & & \\
\hline 延床面積平 & 均值 $\left(\mathrm{m}^{2}\right)$ & 507.0 & 929.0 & 2220.0 & & \\
\hline 件 & & 299 & 2 & 1 & & \\
\hline & & $\mathrm{S} 0, \mathrm{H} 1$ & $\mathrm{~S} 1, \mathrm{H} 1$ & {$[\mathrm{~S} 2, \mathrm{H} 1$} & & ド \\
\hline 焼損床面積 & 平均值 & 23.6 & 19.8 & 32.0 & & \\
\hline$\left(\mathrm{m}^{2}\right)$ & 標準偏差 & 63.9 & 80.4 & 75.1 & & 要 \\
\hline 焼損率 & 平均值 & 9.2 & 3.6 & 3.4 & 1 & \\
\hline$(\%)$ & 標準偏差 & 24.0 & 14.1 & 8.8 & & T \\
\hline 延床面積平 & 均值 $\left(\mathrm{m}^{2}\right)$ & 421.4 & 5112.0 & 2299.3 & & 1 \\
\hline 件 & & 165 & 24 & 8 & & \\
\hline & & $\mathrm{S} 0, \mathrm{H} 2]$ & $\mathrm{S} 1, \mathrm{H} 2$ & {$[\mathrm{~S} 2, \mathrm{H} 2$} & & 卜 \\
\hline 焼損床面積 & 平均值 & 5.8 & 12.3 & 4.1 & & \\
\hline$\left(\mathrm{m}^{2}\right)$ & 標準偏差 & 16.6 & 59.0 & 25.5 & & \\
\hline 焼損率 & 平均值 & 1.4 & 1.2 & 0.3 & 2 & \\
\hline$(\%)$ & 標準偏差 & 5.3 & 7.8 & 2.2 & & \\
\hline 延床面積平 & 均值 $\left(\mathrm{m}^{2}\right)$ & 1300.1 & 3346.0 & 9095.3 & & \\
\hline 件 & & 124 & 222 & 167 & & \\
\hline
\end{tabular}

任していないが消火訓練を実施している」や「報知設備はあるが、消 火設備はない」などの組合は「火災報告」の中でも非常に少ないので、 それぞれひとつのグループとしてまとめた。

\section{2 「火災報告」分析の結果・考察}

(1) アンケート回答建物のポイント区分別の得点分布

アンケート調査の対象建物をポイント Snと Hnの組み合わせで 9

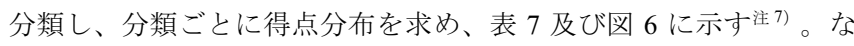
お、図 6、図 7 は分析が可能な該当数となる 6 分類のみ記載した。

表 7 に示すように 185 件の回収したデータのうち、H0 に属するデ ータ数は 5 件と少ないので傾向を論ずることはできない。ハード要 因のポイントが 1 以上であれば (H1,H2 の列)、ソフト要因のポイ ントの増加はアンケートの平均合計得点の増加傾向を示した。

図 6 に各区分におけるアンケート得点の分布状況を示寸。同図 に見られるように、各区分に属するデータ数が少ないため、ソフ ト・ハード要因ともに大きく分散した分布形状となっている。し かし、各図を大きく括って見れば、ポイントが増加すると高得点 となる件数の増加（図の上では多くの件数が右側に集まる）傾向 が認められる。特に、H2 の群に関しては、ソフト要因が向上する とハード要因も平均值が高くなっていた。

図 8 にポイント数を横軸に、アンケート結果における区分ごと の合計平均点を縦軸に関係を示す。この図に明らかなように、ポ イント数が増加すると、サンプル数の少ないものを除いて、得点 は増加傾向にあることが分かる。

（2）ポイント区分別の焼損床面積の累積相対度数

「火災報告」の火災建物もアンケート結果との対応を意図して 同様に 9 分類した。区分ごとに焼損床面積の累積相対度数を図 7 に示し永 7,8)、表 8 に焼損床面積及び焼損率の平均值と標準偏差を 示した。

図 7 の焼損床面積の累積相対度数をみると $\mathrm{H} 1$ では小火の割合 が約 60\%であるが、H2 では約 $80 \%$ と小火の割合が多くなってい る。一方、ソフト要因のポイント変化が焼損床面積の傾向の変化 に及ぼす影響はハード要因のポイント変化ほど大きくないが、

[S2,H2］の群は小火の割合が約 $90 \%$ と高い值を示しており、延 焼拡大の割合も小さくなるものと推定される。

表 8 においても、表 7 の場合と同椂に、消防法令に基づき ［S0,H0］は存在するが、 $[\mathrm{S} 0, \mathrm{H} 1 ］[\mathrm{~S} 0, \mathrm{H} 2 ］$ はない。法令以上の 安全対応をしているものの少なさを示す。

表 8 をもとに、ポイント数を横軸に、縦軸に焼損床面積および 焼損率の平均值を図示したのが図 9 である。焼損床面積に関して は、ソフト要因のポイントが同じであれば、ハード要因のポイン 卜向上に従って焼損床面積は小さくなる傾向を示す。しかし、八 ード要因のポイントが同じ場合には、データ数の少ないものもあ るが、ソフト要因のポイントが高くなっても、必ずしも、焼損床 面積の減少には繋がっていない。 H1 群では S1 で最小值を示し、 $\mathrm{H} 2$ 群では S2 で最大值を示していた。一方、焼損率についてみれ ば、ポイント数の増加に従って急激に值が低減する明確な相関を 示した。

（3）アンケート結果の得点と「火災報告」によるポイント数

ポイント Snと Hnが大きくなる（表 8 で左上から右下へ移動） に従い、概衩アンケート調査の得点の平均値は高くなり、「火災報 
告」の焼損率の平均值は低くなる。また、ソフト要因やハード要因 の一方のポイントが同じでも、他方のポイントが上がるに従って、 得点の平均值は高くなり、焼損率の平均值は低くなる傾向がある。 ハード要因のポイントが 1 以上では、表 7 における右下の欄に移行 するに従って得点分布も高得点側に移り、特異な得点注9」となる建物 の出現は概ね見られない。

そこで、表 7 と 8 における 9 区分のマトリックスの中央区分であ る、 $[\mathrm{S} 1, \mathrm{H} 1]$ が火災報告に示された火災における焼損被害の平均像 を作り出しているとすれば、表 7 の $[\mathrm{S} 1, \mathrm{H} 1]$ のアンケート平均得 点合計（186.8 点）が、表 8 の災報告における [S1,H1] の焼損床 面積平均值 $19.8 \mathrm{~m}^{2}$ 、焼損率 $3.6 \%$ の火災を生み出すと考えられる。 同様に他の区分もそれぞれ対応すると仮定できる。

アンケートの得点を横軸に焼損床面積や焼損率を縦軸にして、図 10 が得られる。当然この図においても、アンケートの得点と焼損床 面積に関しては明確な関係は述べられない。しかし、結果的には両 者の関係は、焼損率に関してはアンケート得点を被害規模に読み替 えても不都合がなく、アンケートの得点と火災被害規模が一体化す るものと考えた。

しかし、アンケート調査と「火災報告」の母集団が異なっている ので今後更なるデータの蓄積が必要であることに加えてソフト要因 とハード要因の得点の重みが同じであるために評価軸上で歪が生じ ている可能性がある。今後、データ蓄積を続ければ、アンケート調 查の項目数ならびに各項目の評価重みが確認され、評価できる可能 性がある。

\section{5 アンケート結果と「火災報告」の結合のための焼損率の推計}

4 章の検討で、有意な関係が認められたポイント数と焼損率につ いて、統計的な意味合いがどの程度であるのかにつき、数量化 I 類 を用いて検証する。

アンケート結果と「火災報告」は本来別個のものであるが、アン ケートの得点の持つ意味を明確にするために、別の調查結果である 「火災報告」の焼損程度の区分と関連付けることが必要と考えた。 そこで、アンケートと「火災報告」に共通する調查項目に着目した。 すなわち、ソフト要因（「防火管理者の選任状況」「消火訓練の実施 状沉」) とハード要因(「報知設備設の置状況」「消火設備設置の状況」) の 4 項目を説明変数、焼損率注 ${ }^{10)}$ を目的変数として、数量化 I 類の 分析を行い、回帰式を求めた。

焼損率の推計は、表 4 のように分類して分析した場合、および全 建物を一括で分析した場合を行い、重相関係数の值を検討すること で、焼損率予測の精度の検討を最初に行った。回帰式の結果を表 9 に示す。なお、焼損率は量的変数であるが、防火管理者の状況など 説明変数は全て質的変数であるので、結果は段階的に示されるため、 本手法での焼損率の推計は、建物ごとのソフト・ハード要因の状況 の充実度合による損害の概要把握を目的としている。

重相関係数は、全建物一括の場合（表 9 「全建物」欄）が最も大 きく、表 4 による延床面積で分割した場合（建物区分ごと）はいず れも低い值となった。建物区分ごとの場合に重相関係数が低い值と なるのは、4 項目の組合せ（計 16 組）のうち発生する組合せが建物 区分ごとに限定されまた該当件数がごく少数の組合せも多いなど、 建物区分ごとには説明変数としての 4 項目の採用に限界がある（表
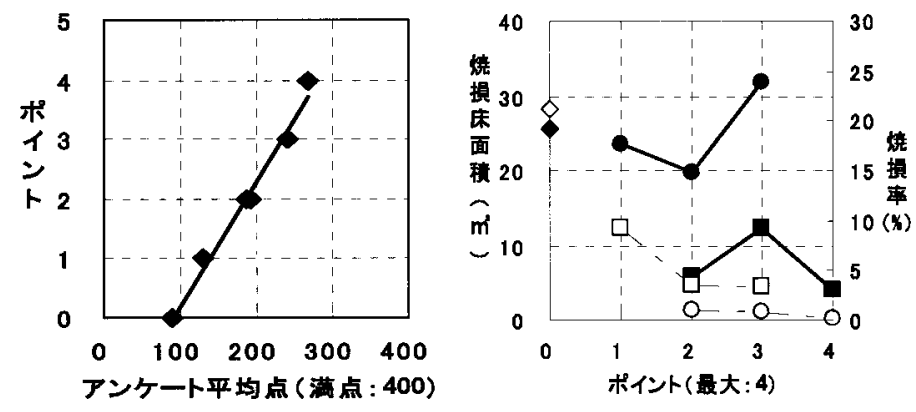

図 8 建物群ごとの得点と ポイント

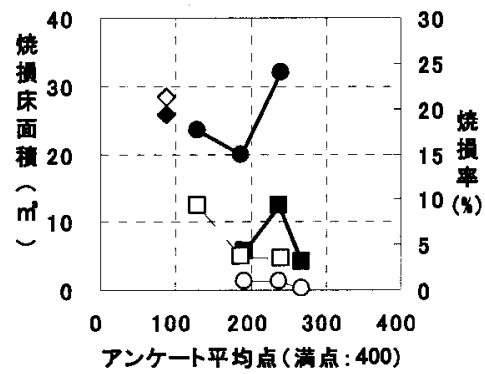

図 9 建物群ことのポイント と蜞損床面積 - 焼損率

図 10 建物群ごとのアン

ケート得点と焼損床面積

9 中の※補足説明を参照）データでの解析となることが主な理由で ある。以上の検討を基に、事務所建物に関しては、全建物一括で求 めた回帰式を採用する。

\section{6 建物の火災安全性評価手法の提案}

\section{1 総合的な簡易指標としての火災安全指数の提案}

4 章の分析では、アンケートによる得点は、さまざまな階層の建 物規模のデータを蓄積すること、各項目に与えた配点について精査 することによって、ソフト要因およびハード要因ともに概ね正規分 布と仮定できそうであることが分かった。しかし、これらの得点は 見掛け上連続量の形態を呈しているが、上記のように各項目は質的 な変数であるから、簡易指標としての総合的な火災安全指数も当然 なこととして、段階的な指数であることが適切であると考えた。ま た、5 章では、アンケートと「火災報告」と共通する項目が 4 項目 と少ないことから重相関係数もそれほど高くないが、4 個の説明変 数の良し悪しによって焼損率や焼損床面積の大小を推計できる可能 性を示した。また、5 章の分析からも、回帰式から推計されるこれ ら焼損率に係わる数值も概要を把握するための段階的な数值として 捉えるのが現在のところ適切であると考えた。

以上のことから、ここで提案する簡易指標としての火災安全指数 は、4 章の方式によるソフト要因及びハード要因の各得点、両者の 総得点などを基準化して例えば、5 段階程度の数值とし、それぞれ の指数と上記回帰式で求められた焼損率などを関連付ければ、単体 建物の弱点を明確に示すことが出来るとともに、複数の異なる建物 の性能比較なども比較的簡便に行いやすくなると考えた。

火災安全指数は、ソフト要因別（ソフト指数）、ハード要因別（ハ 一ド指数）に計算し、ソフト指数とハード指数を総合した指数（総 合指数）をさらに計算することとする。

図 4 に示したソフト要因、ハード要因ごとの得点分布を正規分布 
と仮定し、平均点と標準偏差を利用して建物の火災安全性を評価す る指数を作成した (表 11 参照)。指数の範囲は、0.0〜 5.0 であり、 実用性を考慮してランク表示は 1 刻みである。また指数作成に使用 した母集団建物の平均值は 2.5 となるように作成し、平均值から 1 $\sigma$ を指数 1.0 の差とした。

\section{2 建物の評価例}

アンケートの中から評価建物として 3 例抽出した。対象とした建 物について、アンケートによる得点およびアンケートと「火災報告」 との共通調查項目の充実状況（ポイント; 本稿 4.2 参照）を表 10 に 示す。

・事務所 A：ソフト・ハード要因ともに良く整備されており、特に ソフト要因が充実している $[\mathrm{S} 2, \mathrm{H} 2]$ 。なお、共用部などの八ード 的対策項目を含む「その他の対策」の得点が平均的であることを、 別途、把握している。

・事務所 B : ソフト・ハードいずれも平均的な事務所建物と同様で ある。ハード要因は平均点を上まわっているが、ソフト要因が平 均点をやや下まわっており、ハードが有効的に機能しない可能性 もある $[\mathrm{S} 1, \mathrm{H} 1]$ 。

- 事務所 $\mathrm{C}$ : 全ての項目で平均点を下まわっており、火災安全上危 険な建物である。ソフト要因が特に低く、また、代表室の対策の 得点も低いため、火災発生時には延焼桩大しや寸い建物であると いえる $[\mathrm{S} 0, \mathrm{H} 1]$ 。

上記の重回帰式を用いて、選んだ 3 対象建物の評価を試みる。重
回帰式で計算した焼損率および焼損床面積の推計結果を表 12 に示 す注 11)。この表に示したように、焼損率の推計值は、事務所Aが最 も小さく約 $0 \%$ 。次いで事務所B、事務所Cの順に大きくなっている。 焼損床面積も同様の傾向にある。表 11 に示す火災安全指数も同様に 事務所Aが最も火災安全指数が高く、B、Cの順で低くなる。

データを蓄積し、更なる検証が必要ではあるが、対象とする建物 の火災安全性能を提案したアンケートで得点化し、それを基に 5 段 階の火災安全指数として示した数值が、「火災報告」の結果のグルー ピングと対応させた回帰式を基にどの程度の火災拡大被害を呈する かを推計する手掛かりとなり得ることが確認できたと判断する。

\section{7 まとめ}

建物の安全性に加えて日常管理状沉までを含めた火災安全性評価 を行う方法の提案を目指し、既存建物に対するアンケート調查の分 析、および「火災報告」の分析を行った。また、「火災報告」の分析 に際して、二つの調査に共通する調查項目を利用しお互いに関連さ せることを試みた。すなわち、既存建物の安全性（得点）と火災を 生じた建物の安全性（焼損床面積）を関連づけた。その結果、共通 項目のポイントが高い建物ほど高得点あるいは焼損床面積が少ない、 ポイントが低い建物ほど低得点あるいは焼損床面積が大きいという、 同じ傾向が得られた。

試作したアンケートの結果を用いて対象建物の火災安全性をラ ンク付け（火災安全指数化）が可能であり、そのランク結果から焼

表 9 ソフト・ハード 4 項目による焼損率の回帰式 (事務所 (非木質系))

\begin{tabular}{|c|c|c|c|c|c|c|c|c|c|c|c|c|c|c|}
\hline $\begin{array}{c}\text { 建物区分 } \\
\text { (延床面積の区分) }\end{array}$ & & 定数項 & & 防火管 & 含理者の項 & & 消火 & 訓練の項 & & 消火 & 設備の項 & & 報知設備の項 & 重相関係数 \\
\hline \begin{tabular}{|l} 
全建物 \\
(1012件)
\end{tabular} & : & 27.8 & + & $\begin{array}{r}0.0 \\
-2.0\end{array}$ & $\begin{array}{l}\text { (未選任) } \\
\text { (選任) }\end{array}$ & & $\begin{array}{r}0.0 \\
-0.7\end{array}$ & $\begin{array}{l}\text { (未実施) } \\
\text { (実施) }\end{array}$ & + & $\begin{array}{r}0.0 \\
-18.8\end{array}$ & $\begin{array}{l}\text { (設置なし) } \\
\text { (設置) }\end{array}$ & + & $\begin{aligned}0.0 \text { (設置なし }) \\
-6.6 \text { (設置) }\end{aligned}$ & 0.43 \\
\hline $\begin{array}{l}0 \sim 150 \mathrm{~m}^{2} \\
(177 \text { 件 })\end{array}$ & : & 44.2 & + & $\begin{array}{r}0.0 \\
-8.5\end{array}$ & $\begin{array}{l}\text { (未選任) } \\
\text { (選任) }\end{array}$ & + & & $(※)$ & + & $\begin{array}{l}0.0 \\
8.8\end{array}$ & $\begin{array}{l}\text { (設置なし) } \\
\text { (設置) }\end{array}$ & + & $\begin{aligned} 0.0 \text { (設置なし) } \\
-35.0 \text { (設置) }\end{aligned}$ & 0.11 \\
\hline $\begin{array}{l}150 \sim 300 \mathrm{~m}^{2} \\
(133 \text { 件) }\end{array}$ & : & 13.2 & + & $\begin{array}{l}0.0 \\
5.5\end{array}$ & $\begin{array}{l}\text { (未選任) } \\
\text { (選任) }\end{array}$ & + & & $(※)$ & + & $\begin{array}{r}0.0 \\
-5.7\end{array}$ & $\begin{array}{l}\text { (設置なし) } \\
\text { (設置) }\end{array}$ & + & $\begin{array}{ll}0.0 \text { (設置なし) } \\
0.7 \text { (設置) }\end{array}$ & 0.12 \\
\hline $\begin{array}{l}300 \sim 1000 \mathrm{~m}^{2} \\
(283 \text { 件) }\end{array}$ & : & 4.2 & + & $\begin{array}{l}0.0 \\
2.1\end{array}$ & $\begin{array}{l}\text { （未選任） } \\
\text { (選任) }\end{array}$ & + & $\begin{array}{r}0.0 \\
-2.7\end{array}$ & $\begin{array}{l}\text { (未実施) } \\
\text { (実施) }\end{array}$ & + & $\begin{array}{l}0.0 \\
1.0\end{array}$ & $\begin{array}{l}\text { (設置なし) } \\
\text { (設置) }\end{array}$ & + & $\begin{aligned} 0.0 \text { (設置なし) } \\
-3.9 \text { (設置) }\end{aligned}$ & 0.13 \\
\hline $\begin{array}{l}1000 \mathrm{~m}^{2} \text { 以上 } \\
\text { (419件) }\end{array}$ & & 2.9 & + & $\begin{array}{l}0.0 \\
0.0\end{array}$ & $\begin{array}{l}\text { (未選任) } \\
\text { (選任) }\end{array}$ & & $\begin{array}{r}0.0 \\
-0.1\end{array}$ & $\begin{array}{l}\text { (未実施) } \\
\text { (実施) }\end{array}$ & + & $\begin{array}{r}0.0 \\
-2.6\end{array}$ & $\begin{array}{l}\text { (設置なし) } \\
\text { (設置) }\end{array}$ & + & $\begin{aligned} 0.0 & \text { (設置なし) } \\
-0.1 & \text { (設置) }\end{aligned}$ & 0.17 \\
\hline
\end{tabular}

(※) 重回帰分析の結果、決定係数が低く重回帰式の項として選択していない項を示す

表 10 評価例建物のアンケート結果

\begin{tabular}{|c|c|c|c|c|c|c|c|}
\hline \multirow{2}{*}{ 建物名 } & \multicolumn{2}{|c|}{ ポイント } & \multicolumn{4}{|c|}{ 得点 } & \multirow{3}{*}{$\begin{array}{c}\text { 床面積 } \\
\left(\mathrm{m}^{2}\right)\end{array}$} \\
\hline & ソフト & ハード & 日常管理 & 設備点検 & 代表室の対策 & その他の対策 & \\
\hline 平均点 & - & - & 47.8 & 61.9 & 57.7 & 67.8 & \\
\hline 事務所A & 2 & 2 & 92.3 & 84.6 & 79.2 & 70.0 & 2140 \\
\hline 事務所B & 1 & 2 & 46.2 & 61.5 & 62.5 & 70.0 & 5990 \\
\hline 事務所C & 0 & 1 & 30.8 & 38.5 & 41.7 & 60.0 & 848 \\
\hline
\end{tabular}

表 11 評価例建物の火災安全指数

\begin{tabular}{|c|c|c|c|}
\hline & ソフト指数 & ハード指数 & 総合指数 \\
\hline 平均 & 2.5 & 2.5 & 2.5 \\
\hline 事務所A & 4.3 & 3.3 & 3.9 \\
\hline 事務所B & 2.5 & 2.7 & 2.6 \\
\hline 事務所C & 1.5 & 1.7 & 1.6 \\
\hline
\end{tabular}

表 12 評価例建物の焼損率 - 焼損床面積の概算

\begin{tabular}{|c|c|c|c|c|c|c|c|c|c|c|c|c|c|c|c|}
\hline 建物名 & & 定数項 & & 防火管 & 管理者の項 & & 消火 & 訓練の項 & & 消火 & 設備の項 & & 報知設備の項 & 焼損率 & 燒損床面積 \\
\hline 全建物 & : & 27.8 & + & $\begin{array}{r}0.0 \\
-2.0\end{array}$ & $\begin{array}{l}\text { (未選任) } \\
\text { (選任) }\end{array}$ & + & $\begin{array}{r}0.0 \\
-0.7\end{array}$ & $\begin{array}{l}\text { (未実施) } \\
\text { (実施) }\end{array}$ & + & $\begin{array}{r}0.0 \\
-18.8\end{array}$ & $\begin{array}{l}\text { (設置なし) } \\
\text { (設置) }\end{array}$ & + & $\begin{aligned} 0.0 \text { (設置なし) } \\
-6.6 \text { (設置) }\end{aligned}$ & & \\
\hline 事務所A & 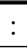 & 27.8 & + & -2.0 & （選任） & + & -0.7 & (実施) & + & -18.8 & (設置) & + & -6.6 (設置) & $0.0 \%$ & $0 \mathrm{~m}^{2}$ \\
\hline 事務所B & & 27.8 & + & -2.0 & （選任） & + & 0.0 & (未実施) & + & -18.8 & (設置) & + & -6.6 (設置) & $0.4 \%$ & $24 \mathrm{~m}^{2}$ \\
\hline 事務所C & & 27.8 & + & 0.0 & (未選任) & + & 0.0 & (未実施) & + & 0.0 & (設置なし) & + & -6.6 (設置) & $21.2 \%$ & $180 \mathrm{~m}^{2}$ \\
\hline
\end{tabular}


損床面積、焼損率を推測できることを導いた。今後は、設問項目の 設定やソフト要因とハード要因の得点の重み等よりデータ蓄積の問 題、評価精度の向上、および他用途建物への適用の可能性の検討を 行う必要がある。

\section{注}

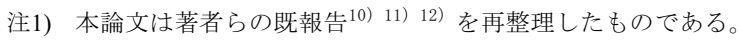

注2) 消防法第 24 条、消防組織法第 22 条による防火対象物に関する火元建 物データであり、日本国内で発生する全ての火災（一部例外あり）に 対して、防火管理者の選任状況や消火設備の設置状況、出火源や着火 物、消火の状況などについて収集されているものである。

注3）焼損率=焼損床面積/延床面積である。

注4） 入手データは 1995 年〜2002 年だが、1995 年は阪神淡路大震災のデー 夕も入っており、日常災害としての火災リスクを検討する本論文の正 確性を損なう可能性があるため、1996 年〜2002 年とした。

注5）材料の耐火性に着目して、防災行政研究会「「火災報告」取扱要領ハン ドブック」に基づいて分類した、「準耐火建築物(非木質)」「耐火建築物」 を合せて「非木質系」とした。

注6）表 6 に示したように、ソフト,ハード共に 2 項目（それぞれ最大 2 ポイ ント計最大 4 ポイント) と寸ることが分析のしや寸さから適切である。 消防法第八条に従い防火管理者を選任していれば、消防法施行令第四 条に従い消防計画書を作成し消火訓練も実施しているのが消防法令に 従った管理である (もちろん違法な管理である可能性もあるが)。防火 管理者を選任していないのに消防計画書を作成することはほとんどな い（消防計画書を作成していれば防火管理者を選任）こと、従って、 防火管理者選任を項目として採用寸れば、消防計画書の作成を含める 必要はないと判断した。また、消火訓練の実施は、消防計画書同様に 防火管理者の責務であるが、防火管理者を選任していない（消防計画 書も作成していない）が、消火設備が設置（法定設置か自主設置かは 問わず）されていれば、消火訓練を実施することはあるので、ハード 項目として採用されている消火設備設置との対応も考慮し採用した。

注7) 分類した建物群の得点の度数分布(図 6)は、[H0]の群の件数は少なく一 般化するにはデー夕の蓄積が必要であるため、[H1]以上を示す。

注8) 図 7 は、焼損床面積を横軸（対数軸）、累積相対度数を縦軸にとり、焼 損床面積と建物の割合を表わしたグラフで、グラフが上側であるほど 焼損床面積が小さい範囲で収まる建物が多いこと、すなわち火災拡大 の危険が少ない建物が多いことを示している(文献 9 参照)。

注9）例えば図 6(f)はソフト・ハード共に充実している群だが、得点分布も高 得点側に多く、非常に低い得点の建物は現われていない。

注10) 延床面積が大きいほど焼損床面積も大きくなることが推測でき、単純
に焼損床面積を目的変数とした回帰式を求めた場合、不自然な結果 $(一$ 般的に延床面積が大きいほど消防法令による規制は厳しくなり、焼損 床面積を抑えられると予想できるが、同時に焼損床面積も大きくなる ため）も予想されるため、焼損率を採用した。

注11) 焼損率の計算結果が $0 \%$ 以下の場合は $0 \%$ とした

\section{参考文献}

1）関沢愛：住宅火災の初期拡大危険の分析，火災,Vol.27, No.6(111)，1997 年

2) 関沢愛 : 木造住宅における火炎拡大危険の要因分析、日本建築学会論文報 告集，第 284 号，1979 年

3）野崎洋之・小林裕：統計デー夕に基づく火災リスク評価手法について（そ の1）火災リスク評価手法の全体構成と火災の発生確率，日本火災学会研 究発表会概要集, pp.350-351，2004

4）野崎洋之・小林裕：統計デー夕に基づく火災リスク評価手法について（そ の2) 火災リスク曲線の定式化法の提案, 日本火災学会研究発表会概要集, pp.352-353, 2004

5) 小林裕・野崎洋之：統計データに基づく火災リスク評価手法について（そ の 3）建物規模別の火災リスクの比較，日本火㷋学会研究発表会概要集， pp.108-111, 2005

6) 水野智之 : 火災統計にみた建物規模別の火災損害, 日本建築学会大会学術 講演梗概集，A-2 分冊，pp.197-198，2003

7）水野智之：火災統計にみた建物規模別・構造別火災損害について，日本建 築学会大会学術講演梗概集, A-2 分冊, pp.281-289, 2005

8) 水野智之 : 正規化リスク曲線を用いた建物火災損害の統計分析, 日本建築 学会大会学術講演梗概集, A-2 分冊, pp.183-184, 2006

9) 佐藤博臣・村井裕樹・志田弘二・栗岡均 : 火災統計デー夕に基づく火災拡 大危険評価法，日本建築学会環境系論文集 第 614 号 pp.1 8，2006

10）佐藤博臣・村井裕樹 - 栗岡均・志田弘二 : 火災安全性能の得点化方法の 提案 建築物の火災安全性能の評価方法構築に関寸る研究 その 1 , 日本 建築学会大会学術講演梗概集 A-2 pp.177〜 178，2006

11)村井裕樹・佐藤博臣・栗岡均・志田弘二 : 火災安全性能に関するアンケー 卜項目之焼損面積の関係 建築物の火災安全性能の評価方法構築に関する 研究 その 2 , 日本建築学会大会学術講演梗概集 A-2 pp.179 180, 2006

12)栗岡均・佐藤博臣・村井裕樹 - 志田弘二 : 既存建物の評価と火災安全指数 の提案 建築物の火災安全性能の評価方法構築に関する研究 その 3 , 日 本建築学会大会学術講演梗概集 A-2 pp.181 182，2006

13)「既存不適格建築物の防火性能診断法に関する調查」、国土交通省・国土技 術政策総合研究所資料 No.369，p.134 表 6.3, 2007.1

(2007年 7 月 9 日原稿受理，2008年 1 月 22 日採用決定） 